\title{
Techno-economic Analysis in the Modification of 100 TEUs Container Carrier by Using LNG as Dual Fuel System
}

\author{
Agoes Santoso $^{1}$, Beny Cahyono ${ }^{2}$, Edi Jadmiko ${ }^{3}$, Kevin Garsia $^{4}$
}

(Received: 01 August 2018 / Revised: 07 May 2019 / Accepted: 24 June 2019)

\begin{abstract}
Indonesia is no longer known as an oil exporter country but Indonesia has a large deposit of natural gas. This situation will bring the conversion from using fuel oil to gas. It will also support IMO Regulation such as MARPOL 73/78 Annex VI Tier III which was stringent in the regulation to bring the world to achieve near zero emission level. One of the methods to comply with IMO tier III is using gas as a fuel. Therefore, the ship efficiency can be overcome by two aspects simultaneously, cheaper and cleaner gas as marine engine fuel. In this paper, LNG as fuel will be applied to 100 TEUs Container Carrier which is consider several technical aspects when the existing ship is modified so that natural gas can be used safely and well. Things to consider in this LNG re-design are; the volume of tank, bunkering station system, and the Gas Valve Unit $(G V U)$. In addition, this design will also analyze the costs required to modify the vessel so that it can use dual fuel (MDO and $L N G$ ) as well as cost comparison when using single fuel (MDO).
\end{abstract}

Keywords—Dual Fuel, Emission, Gas Powered Vessel, LNG, MDO, Tier III IMO

\section{INTRODUCTION ${ }^{1}$}

$\mathrm{E}$ maritime sector. International Maritime Organization (IMO) decided to reduce the amount of the pollution generated by ships which is a part of the source of global warming that is getting worse at this moment. IMO control the emission reduction based on the level call as Tier I, Tier II, and Tier III. One of the ways to make the eligible solution for emission reduction according to IMO tier III is by using gas as fuel and the dual fuel implementation is the most applicable to the ship [1]. Dual Fuel means two fuels which one of them is diesel fuel and the other one can be gas fuel like LPG, LNG, and $\mathrm{CNG}$ or methane [2],[3]

Indonesia is a country that has a large amounts of natural gas deposit [4]. In the one hand, Indonesia is a IMO member that it must implement the tier III in the near future. LNG offers benefits in both technical and economic aspects. The cleaner LNG is cheaper than the diesel oil, either HFO or MDO [5].

Dual fuel engine with LNG has been implemented since 2000 even still as alternative fuel. With the many advantages such as less emission, cutting the operational

Agoes Santoso, Department of Marine Engineering, Institut Teknologi Sepuluh Nopember, Surabaya 60111, Indonesia, E-mail: agoes295@gmail.com

Beny Cahyono, Department of Marine Engineering, Institut Teknologi Sepuluh Nopember, Surabaya 60111, Indonesia, E-mail: cak_beny@yahoo.com

Edi Jadmiko, Department of Marine Engineering, Institut Teknologi Sepuluh Nopember, Surabaya 60111, Indonesia, E-mail: gusjadmiko@gmail.com

Tony Bambang Musriyadi, Department of Marine Engineering, Institut Teknologi Sepuluh Nopember, Surabaya 60111, Indonesia, Email: tobac@its.ac.id

Kevin Garsia, S Department of Marine Engineering, Institut Teknologi Sepuluh Nopember, Surabaya 60111, Indonesia, E-mail: kevin.garsia14@its.mhs.ac.id cost, and fast return on investment, then dual fuel engine can be one of the best options in order to make ship comply with IMO tier III.

Natural gas is stored in liquid (LNG) conditions and when it is used, the LNG would be evaporated before used by the engine. The reason why LNG is one option to comply with MARPOL is because of the nature of LNG characteristic that have low sulfur content and at the combustion process it may produce lower NOx than fuel oil [6].

This paper is organized as follows. In the second section after the introduction, the explanation of the designed container carrier 100 TEUs will be conducted, including ships modification, bunkering system, and LNG transfer from LNG tanks to main engine [7]. Then, analysis about the difference of operational cost between the use of diesel fuel and dual fuel are carried out in the same main engine power to prove the reason why dual fuel should be considered properly.

\section{METHOD}

The first process of this design is getting the general arrangement of Container Carrier 100 TEUs. This could be obtained from certain shipyard which built the ship with these criteria. The general arrangement of 100 TEUs shown in Figure 1 and the data of this ship's general arrangement is shown in Table 1.

One of the methods to modify ships fuel system is by changing the main engine that use diesel fuel only to dual fuel engine that able to use diesel fuel and gas fuel [8]. To comply the new dual fuel engine can be operated normally like the existing engine, and engine propeller matching (EPM) should be done. By using the engine propeller matching methods, then the percentages of clean condition should be over $80 \%$ to $90 \%$ and rough condition is $100 \%$ in order to match the new dual fuel engine usage. The specification of the new engine that comply with this requirement is shown in Table 2. 
TABLE 1.

SHIP'S GENERAL ARRANGEMENT DATA

\begin{tabular}{ll}
\hline \multicolumn{2}{c}{ Type of data } \\
\hline Length Overall (LOA) & \multicolumn{1}{c}{ Nominal } \\
Length Between Perpendicular & $\pm 76.64(\mathrm{~m})$ \\
(LBP) & \\
Breadth (B) & $\pm 15.60(\mathrm{~m})$ \\
Height (H) & $\pm 4.2(\mathrm{~m})$ \\
Draft (d) & $\pm 3(\mathrm{~m})$ \\
Velocity Service (Vs) & $12(\mathrm{knot})$ \\
Main Engine Power (BHP) & $2 \times 1533(\mathrm{HP})$ \\
\hline
\end{tabular}

TABLE 2 .

SPECIFICATION OF DUAL FUEL ENGINE

\begin{tabular}{ll}
\hline Name of the engine: & Wartsila 6L20DF \\
Power: & $1110(\mathrm{~kW})$ \\
RPM: & 1200 \\
No. of Cylinder: & 6 \\
Bore x Stroke: & $200 \times 280(\mathrm{~mm})$ \\
Mean Effective Pressure: & $2.1 \mathrm{MPa}$ \\
Fuel: & MDO for vessels, LNG \\
\hline
\end{tabular}

TABLE 3 .

MDO AND LNG USAGE IN $\mathrm{M}^{3}$ THAT DETERMINED FROM SHIP'S ENDURANCE

No. Endurance Hours MDO Volume LNG

$\left(\mathrm{m}^{3}\right) \quad$ Volume $\left(\mathrm{m}^{3}\right)$

\begin{tabular}{ccccc}
\hline 1 & $1 \mathrm{x}$ & 80 & 7.1 & 9.23 \\
2 & $2 \mathrm{x}$ & 160 & 14.184 & 18.4392 \\
3 & $3 \mathrm{x}$ & 240 & 21.276 & 27.6588 \\
4 & $4 \mathrm{x}$ & 320 & 28.368 & 36.8784 \\
5 & $5 \mathrm{x}$ & 400 & 35.46 & 46.098 \\
6 & $6 \mathrm{x}$ & 480 & 42.552 & 55.3176 \\
\hline
\end{tabular}

TABLE 4.

SPECIFICATION OF WARTSILA LNGPAC FOR 20 FT AND 40 FT

\begin{tabular}{|c|c|c|c|}
\hline \multicolumn{4}{|l|}{ Frame dimensional (external) } \\
\hline Length & $\mathrm{m}$ & 6058 & 12192 \\
\hline Width & $\mathrm{m}$ & 2438 & 2438 \\
\hline Height & $\mathrm{m}$ & 2591 & 2591 \\
\hline \multicolumn{4}{|l|}{ Tank } \\
\hline $\begin{array}{c}\text { Geometrical Volume (approx. room } \\
\text { temp.) }\end{array}$ & $\mathrm{m}^{3}$ & 20 & 40 \\
\hline $\begin{array}{c}\text { LNG Volume (80\% effective } \\
\text { volume) }\end{array}$ & $\mathrm{m}^{3}$ & 16 & 32 \\
\hline \multicolumn{4}{|c|}{ Other sizes on request } \\
\hline
\end{tabular}
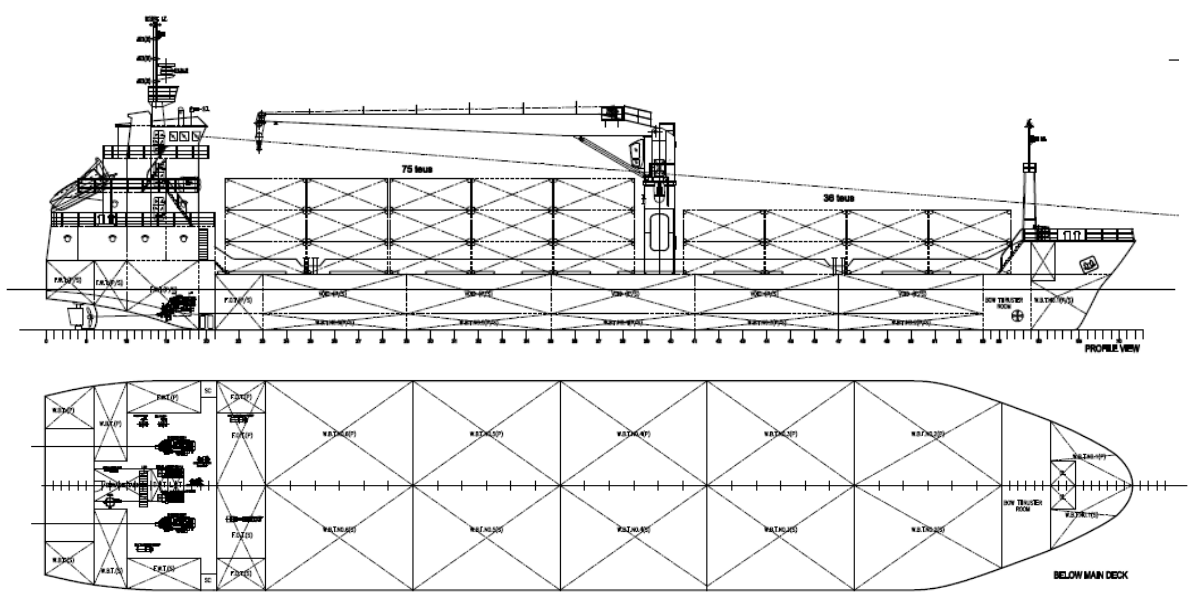

Figure 1. General arrangement of container carrier 100 TEUs 
After met the requirement of EPM, the next step of the design process is how to understanding the own LNG characteristics. LNG is colorless, odorless, boiling point at $-161.5^{\circ} \mathrm{C}$ under normal conditions, flash points at $187.8^{\circ} \mathrm{C}$, auto-ignition temperature occur at temperature of $537^{\circ} \mathrm{C}$ [9]. When compared to HFO tank, LNG tanks can be much larger up to 2.5 times from HFO tanks because of LNG density are lower than HFO and need thermal shield. This enormous tank is one of the disadvantages of using LNG. Consideration of tank position should also be optimized for the safety of the ship during operational and maintenance [9]. IGF Codes control of this procurement in lay out the LNG tank position [10].

The calculation of LNG tanks capacity for designed 100 TEUs ship operation is calculated based on ships route and endurance. Bunkering has been designed for several times of trip in order to shorten bunkering time. Table 3 shows variation of multiple endurance that can be used to consider the bunkering plan. It is optimized among destination, LNG supply availability, and local price. Then the result of bunker calculation for several logical scenarios can be stated as shown by Table 3 as follow:

From the Table 3, the chosen tank used in this modeling work is a tank that can hold for 3 times of endurance with various considerations. Thus, the volume used of each type of fuel can be designed as follows:

- MDO Volume: $60 \mathrm{~m}^{3}$ (same as original GA)

- LNG Volume: $32 \mathrm{~m}^{3}$ (Wartsila LNGPac 40ft)

After designing the volume of LNG tanks, then the position of the LNG tank itself should be considered. By complying the The International Code of Safety for Ships using Gases or other Low-flashpoint Fuels (IGF-Code) [10] is of utmost importance to provide an international legal framework for the gas technology powered ship [11]. The position of the LNG tanks placed as shown in Figure 2.

Then, the next design process is to consider the position of bunkering station for filling sequence of type LNGPac in order to make ship operating normally. IGF Code also has numerous roles in this design process since bunkering station is considered as classified to be a hazardous zone [10]. After some technical aspects that should be considered from hazardous zone, therefore, there are some reduction of the number of container box that can be brought by the ship for safety reason in order to make bunkering station can be operated normally without making any incident risk that may be caused by LNG leakages. Inert gas such as Nitrogen $\left(\mathrm{N}_{2}\right)$ should be provided for the holding place in order to make the bunkering process run smoothly. The result of modified ships includes the bunkering station shown in Figure 2.

Figure 3 shows the schematic diagram of bunkering process. The system includes gas supply and transfer pipe and safety system as an important part under gas circulation system.

Last step for the design process is setup the system for transferring the LNG from each of the storage tank to the main engines. This step usually focuses on a gas valve unit (GVU) capable of ventilating the gas if LNG has an unsuitable pressure before it enters the engines and is capable of shutting down the LNG supply in the case of emergency situations. After passing the GVU itself, the limit length of the gas pipe from GVU to main engine is no more than 10 meters. Figure 4 shows of the safety system from the LNG tank to the main engine.

\section{RESULT AND DISCUSSION}

\section{A. Analysis on Fuel Cost Efficiency}

To know the differences in the operational expenses that should be spent by ship owner, then it is necessary to conduct economic analysis of the fuel usage, especially in the main engine fuel consumption whether in the form of single fuel and dual fuel. The ship route is Surabaya to Balikpapan, where the distance is about $481 \mathrm{~nm}$. If the service speed is $12 \mathrm{knots}$, then the travel time takes about 40 hours, while the loading/unloading time is 80 hours. In order to calculate the fuel consumption of the one main engine, then can use formula (1) as follow:

FC MDO $=$ SFOC MDO $\times$ BHP $\times$ Hours

Fuel Consumption MDO 1x Endurance:

FC MDO

$$
\begin{array}{ll}
=\text { SFOC MDO } \times \text { BHP } \times \text { Hours } \\
=197 \times 1500 \times 80 & \\
=23640000 & \mathrm{gr} \\
=23.64 & \text { ton }
\end{array}
$$

After knowing the use of $100 \%$ MDO fuel in one times endurance, then the modified engine use dual fuel can be calculated its fuel consumption. The ratio used is 50:50 MDOs with LNG; 40\% MDO: 60\% LNG; 30\% MDO: $70 \%$ LNG; and 20\% MDO: $80 \%$ LNG. Then the results can be explained as follow:

$$
\begin{aligned}
& \text { Ratio 50\%MDO : } 50 \% \text { LNG } \\
& 50 \% \mathrm{MDO}=11.82 \text { ton } \\
& 50 \% \text { LNG } \quad=15.37 \text { ton }
\end{aligned}
$$

$$
\begin{array}{cl}
\text { Ratio } 40 \% \mathrm{MDO}: 60 \% & \mathrm{LNG} \\
40 \% \mathrm{MDO} & =9.46 \text { ton } \\
60 \% \mathrm{LNG} & =18.44 \text { ton }
\end{array}
$$

$$
\begin{gathered}
\text { Ratio 30\% MDO : } 70 \% \text { LNG } \\
\text { 30\% MDO } \\
70 \% \text { LNG } \\
=2.09 \text { ton } \\
\end{gathered}
$$

$$
\begin{array}{cl}
\text { Ratio } 20 \% \mathrm{MDO}: 80 \% \mathrm{LNG} \\
20 \% \mathrm{MDO} & =4.73 \text { ton } \\
80 \% \mathrm{LNG} & =24.59 \text { ton }
\end{array}
$$



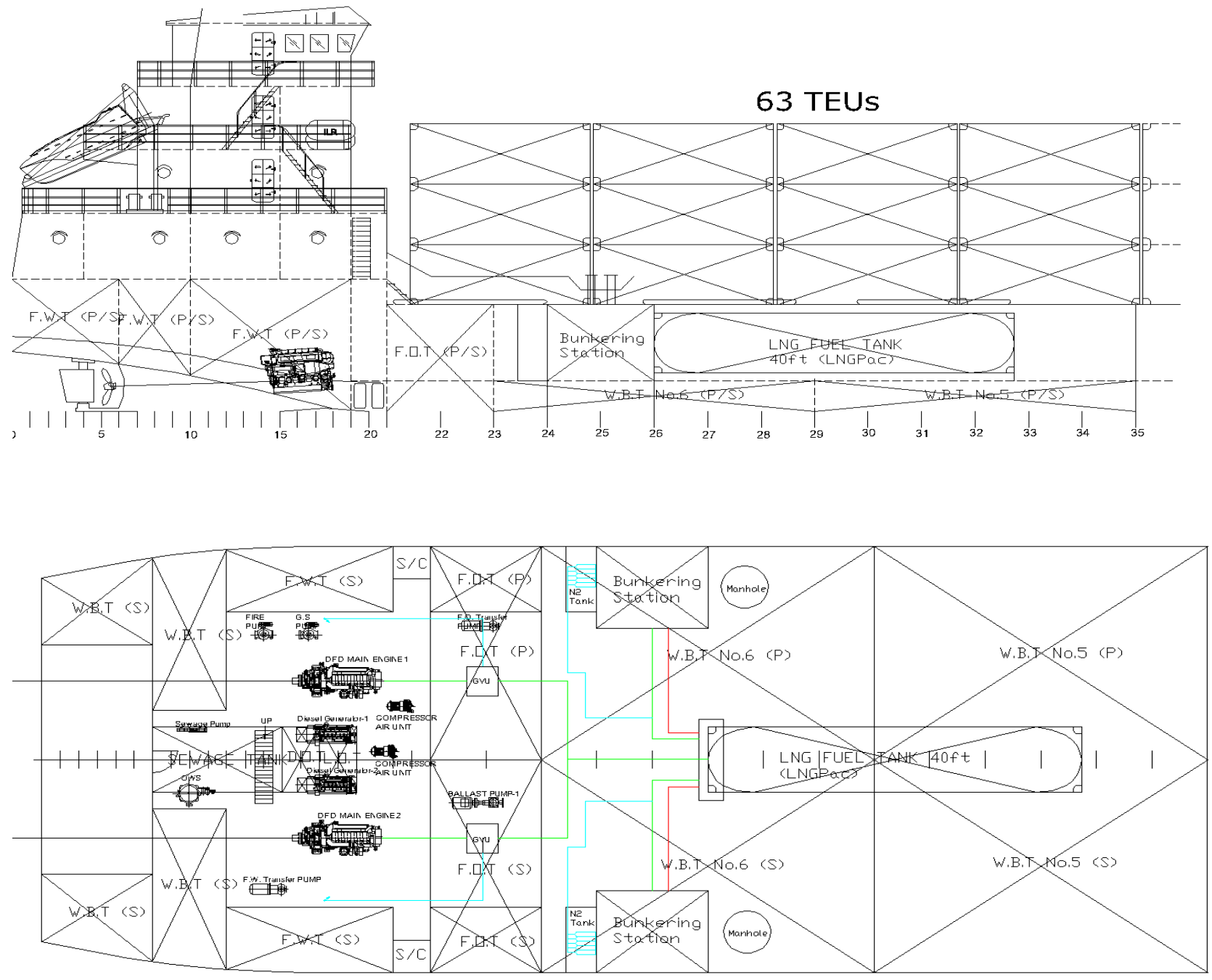

Figure 2. Position of Bunkering Station in ship [7]

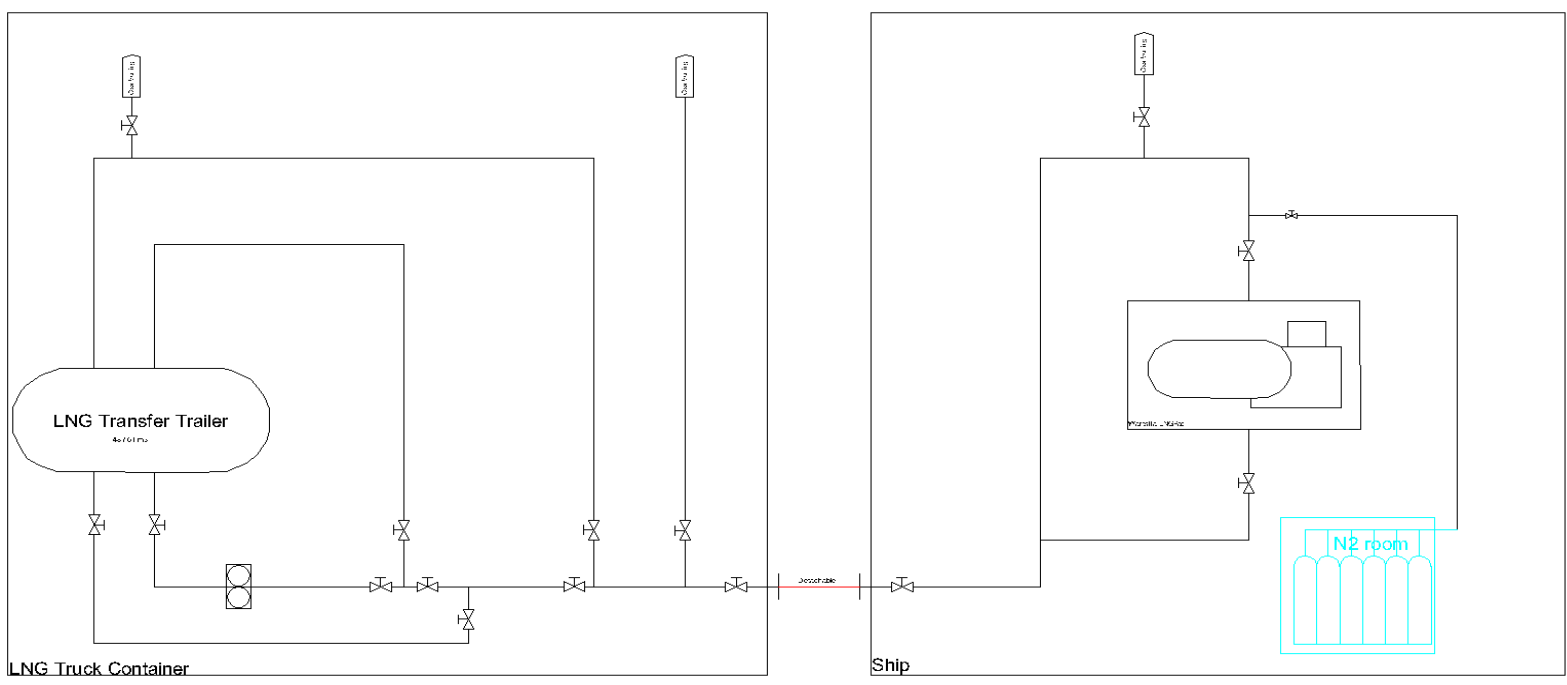

Figure 3. Bunkering Process [7] 
International Journal of Marine Engineering Innovation and Research, Vol. 4(1), Jun. 2019. 39-46 (pISSN: 2541-5972, eISSN: 2548-1479)

TABLE 5 .

PRICES FOR EACH FUEL WITH DETERMINED RATIO

\begin{tabular}{ccccc}
\hline No & $\%$ MDO & \%LNG & $\begin{array}{c}\text { V. MDO } \\
\text { (ton) }\end{array}$ & V.LNG (ton) \\
\hline 1 & 50 & 50 & 11.82 & 15.366 \\
2 & 40 & 60 & 9.456 & 18.4392 \\
3 & 30 & 70 & 7.092 & 21.5124 \\
4 & 20 & 80 & 4.728 & 24.5856 \\
\hline
\end{tabular}

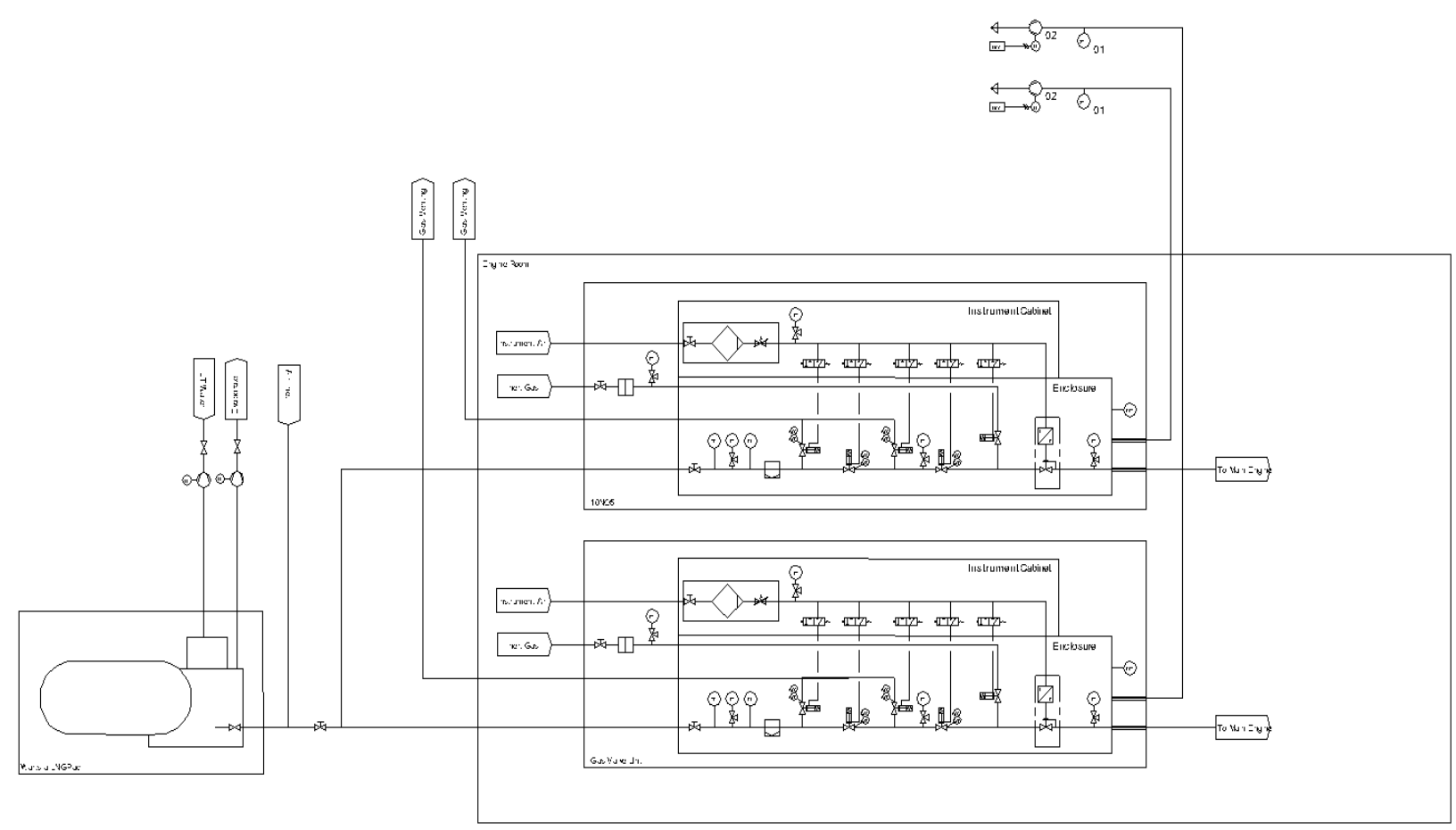

Figure 4. Gas Valve Unit (GVU) system from LNG tanks to main engine [7]

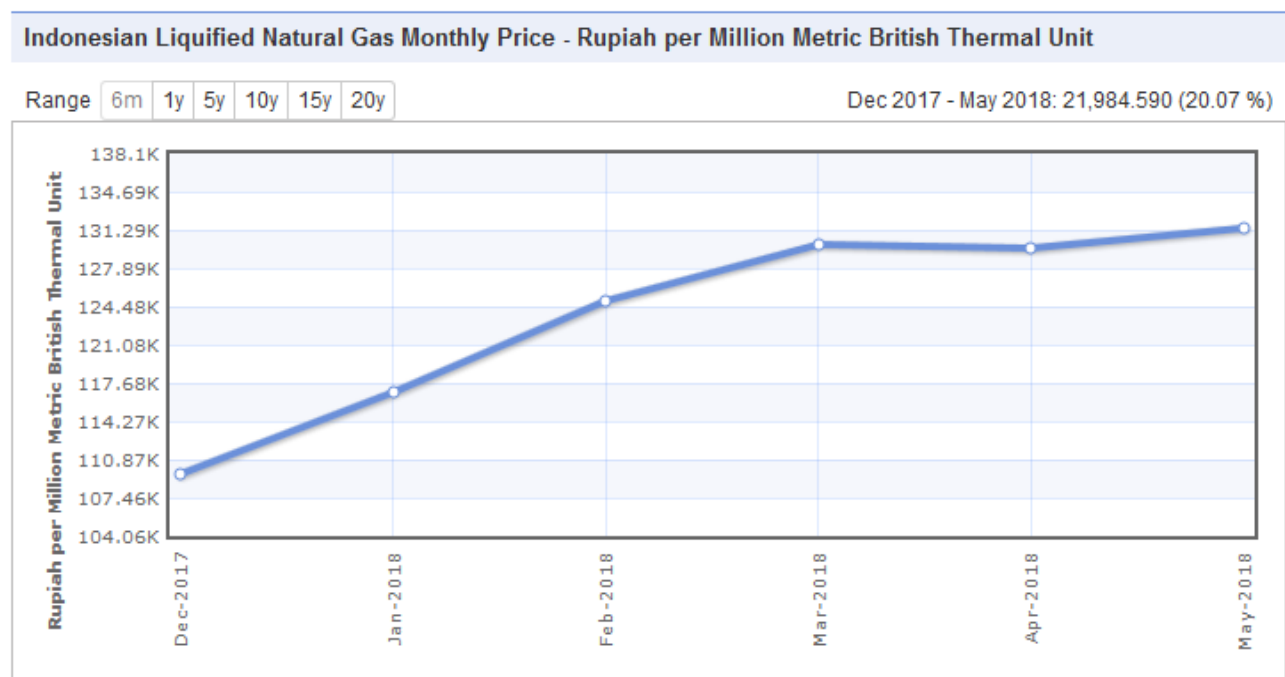

Description: Natural gas LNG (Japan), import price, cif, recent two months' averages are estimates.

Unit: Rupiah per Million Metric British Thermal Unit

Currency: Rupiah

Figure 5. LNG Prices per mmBtu 


\section{Indonesia Diesel prices, Metric ton (gasoline)}

Diesel prices: We show prices for Indonesia from 26-Mar-2018 to 02-Jul-2018. The average value for Indonesia during that period was $14,197,523.81$ Indonesian Rupiah with a minimum of 14,061,879.11 Indonesian Rupiah on 26-Mar-2018 and a maximum of $14,875,747.31$ Indonesian Rupiah on 02-Jul-2018. For comparison, the average price of diesel in the world for this period is $20,372.29$ Indonesian Rupiah

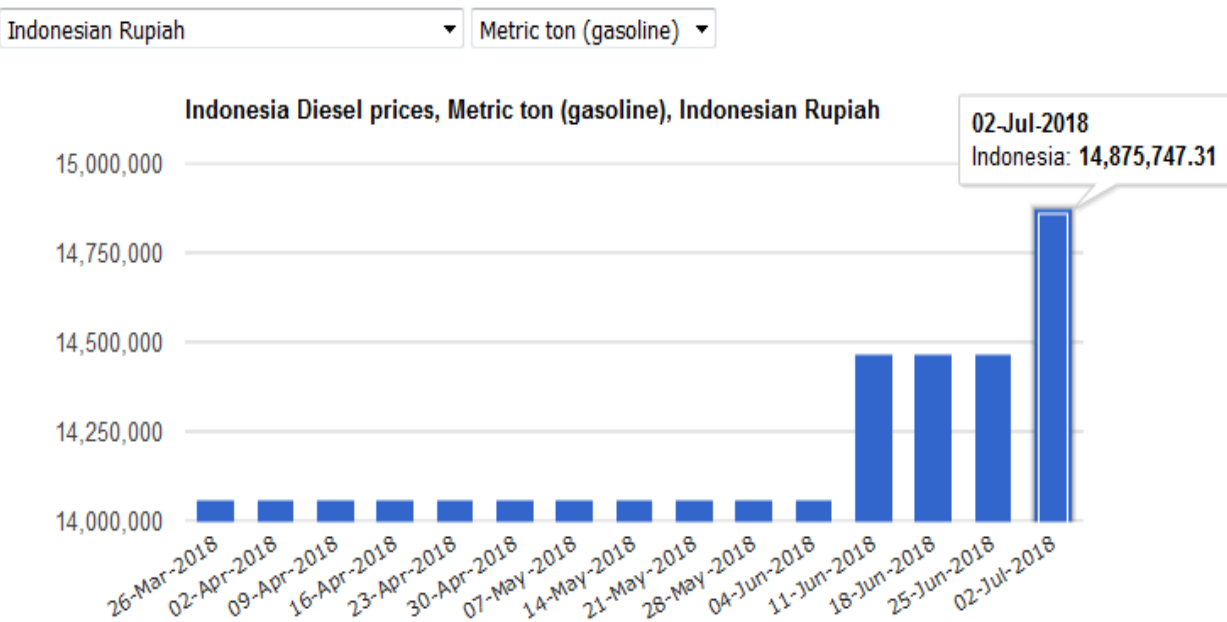

Figure 6. Diesel prices per metric ton

TABLE 6.

PRICES FOR EACH FUEL WITH DETERMINED RATIO

\begin{tabular}{ccc}
\hline V. LNG (mmBtu) & MDO Prices & LNG Prices \\
\hline 820.23708 & $175,831,333.20$ & $107,688,926.23$ \\
984.284496 & $140,665,066.56$ & $129,226,711.48$ \\
1148.331912 & $105,498,799.92$ & $150,764,496.73$ \\
1312.379328 & $70,332,533.28$ & $172,302,281.97$ \\
\hline
\end{tabular}

TABLE 7.

TOTAL PRICES OF EACH FUEL WITH DETERMINED RATIO

\begin{tabular}{cccc}
\multicolumn{4}{c}{ TOTAL PRICES OF EACH FUEL WITH DETERMINED RATIO } \\
No. & $\begin{array}{c}\text { MNG Prices } \\
\text { (IDR) }\end{array}$ & $\begin{array}{c}\text { Total Cost } \\
\text { (IDR) }\end{array}$ \\
\hline 1 & $175,831,333.20$ & $107,688,926.23$ & $283,520,259.44$ \\
2 & $140,665,066.56$ & $129,226,711.48$ & $269,891,778.04$ \\
3 & $105,498,799.92$ & $150,764,496.73$ & $256,263,296.65$ \\
4 & $70,332,533.28$ & $172,302,281.97$ & $242,634,815.25$ \\
\hline
\end{tabular}

TABLE 8.

TOTAL COST OF MDO IN SINGLE FUEL (100\% RATIO)

\begin{tabular}{cccc}
\hline No & $\%$ MDO & V. MDO (ton) & MDO Prices (IDR) \\
\hline 1 & 100 & 23.64 & $351,662,666.41$ \\
\hline
\end{tabular}

TABLE 9.

DIFFERENCE IN FUEL PRICES THAT RATIONED ON DUAL FUEL CONDITION WITH SINGLE FUEL CONDITION

\begin{tabular}{cccc}
\hline No. & Total Cost (IDR) & MDO Prices 100\% & Cost Difference (IDR) \\
\hline 1 & $283,520,259.44$ & $351,662,666.41$ & $68,142,406.97$ \\
2 & $269,891,778.04$ & $351,662,666.41$ & $81,770,888.37$ \\
3 & $256,263,296.65$ & $351,662,666.41$ & $95,399,369.76$ \\
4 & $242,634,815.25$ & $351,662,666.41$ & $109,027,851.15$ \\
\hline
\end{tabular}

TABLE 10.

EFFECTIVE NUMBER OF VOYAGE THAT USE ASSUMPTIONS UNDER CERTAIN CONDITIONS

\begin{tabular}{cccc}
\hline No & Effective days & 1x Effective Voyage & Total Voyage per year \\
\hline 1 & 316 & 3.5 & 90 \\
2 & 300 & 3.5 & 85 \\
\hline
\end{tabular}


TABLE 11.

PRICE DIFFERENCE PER YEAR (UNDER ANNUAL SURVEY)

\begin{tabular}{cccc}
\hline & & & \\
No & Cost Difference (IDR) & Total voyage per year & Cost Difference (IDR) per Year \\
& & 90 & $6,132,816,627.39$ \\
2 & $68,142,406.97$ & 90 & $7,359,379,952.87$ \\
3 & $81,770,888.37$ & 90 & $8,585,943,278.35$ \\
4 & $95,399,369.76$ & 90 & $9,812,506,603.82$ \\
\hline
\end{tabular}

TABLE 12.

PRICE DIFFERENCE PER YEAR (UNDER INTERMEDIATE SURVEY OR SPECIAL SURVEY)

\begin{tabular}{cccc}
\multicolumn{4}{c}{ PRICE DIFFERENCE PER YEAR (UNDER INTERMEDIATE SURVEY OR SPECIAL SURVEY) } \\
\hline \multirow{2}{*}{ No. } & $\begin{array}{c}\text { Cost Difference } \\
\text { (IDR) }\end{array}$ & $\begin{array}{c}\text { Total voyage } \\
\text { per year }\end{array}$ & $\begin{array}{c}\text { Cost Difference (IDR) } \\
\text { per Year }\end{array}$ \\
\hline 1 & $68,142,406.97$ & 85 & $5,792,104,592.54$ \\
2 & $81,770,888.37$ & 85 & $6,950,525,511.04$ \\
3 & $95,399,369.76$ & 85 & $8,108,946,429.55$ \\
4 & $109,027,851.15$ & 85 & $9,267,367,348.06$ \\
\hline
\end{tabular}

For LNG ratio, it has been increased by $30 \%$ due to technical characteristic between MDO and LNG as the reason to decide the LNG tank Volume.

Therefore, the calculation above can be summarized in the Table 5. The fuel capacity is calculated based on one time endurance. Since the LNG price is calculated as US\$ per mmBtu unit, then it can be converted the ton value to be mmBtu unit, where 1 ton $=53.38 \mathrm{mmBtu}$. Figure 5 shows the LNG prices in IDR per mmBtu. Data taken at May 2018. Figure 6 shows the diesel fuel price in IDR per metric ton. It can be noted that in the same time at May 2018 the gas price is IDR 131.290 per $\mathrm{mmBtu}$ and the diesel price is IDR 14.100.000 per metric ton or IDR 264.144 per equivalent mmBtu. In the other hand, it can be said that the price of gas is about half than diesel fuel.

For changing the LNG from ton to mmBtu, it is needs to be multiplied by 53,38 [12]. When the engine using single fuel alone, then the operational cost of fuel can be stated as Table 8 When compared to the cost of fuel that uses dual fuel, then the difference can be stated in Table 9.

If viewed closely, the cost of ship operation using single fuel is much more expensive than dual fuel at any variety of ratios. This is an example of calculation for one time operational endurance, then fuel consumption per year operational can be calculated as:

Total hours at $1 \mathrm{x}$ Endurance is 80 hours or 3.3 days. Unloading/Loading time is about 2 hours for each port (Balikpapan and Surabaya). Both ports approximately capable of unloading at rate of 50 containers per hour, so the effective hours of voyage are 84 hours or 3.5 days. If the year multiple by the ship need to do annual survey, then the effective days is 361 days. If respective year multiple by the ship need to do intermediate or special survey, then the effective days will be 345 days.

If the assumptions in such conditions as queue time entering the port, refueling time, and the existence of a national holiday that allows not doing ship to voyage totaled around 45 days, then the total voyage per year can be summarized in Table 10 .

No. 1 shows the condition where in the year $\mathrm{x}$, the ship need to do the annual surveys. No. 2 for the condition where in the year $\mathrm{x}$, the ship need to do the intermediate or special surveys.
After knowing the total voyage per year, then it can be taken into account the difference of fuel price per year. The result is shown in Table 11 for condition when annual survey carried out. Table 12 for condition when the intermediate survey or special survey should be done.

Table 11 and Table 12 also explore the representative of the operational condition in several composition of duel. No.1 condition is when MDO ratio is $50 \%$ and the LNG ratio is $50 \%$. No. 2 condition is when MDO ratio is $40 \%$ and LNG ratio is $60 \%$. No. 3 condition is when the MDO ratio is $30 \%$ and $\mathrm{LNG}$ ratio is $70 \%$. And finally No.4 condition is when the MDO ratio is $20 \%$ and the LNG ratio is $80 \%$.

When all the figures reviewed based on the total price differences per year, then the range value of billions rupiah would need to be considered in the scheme, then strategic for using dual fuel is in a favorable position compared to single fuel. Converting of the existing single fuel plant to the dual fuel system is also not difficult [13]. The figures calculated for one engine only. Actually the 100 TEUs Container Carrier designed for using twin engine [7], then the number from Table 11 and Table 12 can be multiplied by two.

\section{CONCLUSION}

Dual Fuel Engine has many advantages, especially in terms of minimum emissions level, saving expenditures, faster investment returns, and possibly cut large amount of the operational costs that significantly contributes to the ship owner benefits. Conversion to Dual Fuel system also a proven works that already done in many types of ships at the moment.

Expenditure required for single fuel (MDO) operation is different from dual fuel (MDO and LNG). This can be seen in Table 11 and Table 12 which show the difference of fuel cost both in single trip and annual voyage. Dual fuel system attractively shows the possibility for saving money to maximum value of IDR 9.26 billion in yearly operation time.

\section{REFERENCES}

[1] L. Wei, P. Geng, "A Review on a Natural Gas/Diesel Dual Fue Combustion, Emissions, and Performance," Journal of Fuel Processing Technology 142, pp. 264-278, 2016. 
[2] M.M. Elgohary, I.S. Seddiek, and A.M. Salem, "Overview of alternative fuels with emphasis on the potential of liquefied natural gas as future marine fuel," Proc IMechE Part M: J Engineering for the Maritime Environment 1-11, 2014.

[3] S. Semin, A. Iswantoro, and F. Faris, "Performance and NOx Investigation on Diesel Engine using Cold EGR Spiral Tube: A Review," Int. J. Mar. Eng. Innov. Res., vol. 1, no. 3, Jun. 2017.

[4] A. Santoso, "Technical Report of the design of Gas Powered RoPax in part of Feasibility Study of the Project Development Dual Fuel Roro Ferry in the Route Merak Bakahueni,” PT. Gajah, Bandung, 2017.

[5] B. Remley, "Alternative Maritime Fuels", Alion Science and Technology, University of Southern California, 2014.

[6] A. Frederick, "LNG as Marine Fuel", Gas Technology Institute, website; http://fliphtml5.com/dysg/cxxl/basic, 2015.

[7] K. Garsia, "Design of piping system for 100 TEUs Container Carrier which using LNG Fuel," Final Project report in the Department of Marine Engineering ITS, Surabaya, Indonesia, 2019.

[8] I. Bakas, "Module 5 Propulsion and Power Generation of LNG driven Vessels (23th to 27th November 2015- University of Piraeus, Greece), Presentation "Principles of Marine Main Engines running on LNG", 2015.

[9] J. Herdzik, "LNG as a Marine Fuel - Possibilities and Problems", Journal of KONES Powertrain and Transport, Vol. 18, No. 2, 2011.

[10] IMO, The International Code of Safety for Ships using Gases or other Low-flashpoint Fuels (IGF Code)

[11] K. Kolswan, M. Narewski, "Alternative Fuels for Marine Applications', Latvian Journal of Chemistry, No 4, 2012, 398406, 2012.

[12] International Gas Union (IGU), "Natural Gas Conversion Pocketbook", 2012.

[13] A. Tiwari, "Converting a Diesel Engine to Dual-Fuel Engine Using Natural Gas", International Journal of Energy Science and Engineering, vol. 1(5), pp. 163-169, 2015. 